\title{
FORMATION OF GROUPINGS OF MAYFLY LARVAE (Ephemeroptera) IN THE AREA OF SMALL HYDROLOGICAL STRUCTURES, IN THE STREAMS OF THE KAMIENICA NAWOJOWSKA RIVER BASIN (THE SĄDECKIE BESKIDS, POLAND)
}

\author{
ARTUR NIECHWIEJ
}

The Public Jesuit Junior High School in Mysłowice, 19 Powstańców Street, 41-400 Mysłowice, Poland; e-mail: artursi17@wp.pl

\begin{abstract}
Niechwiej A.: Formation of groupings of mayfly larvae (Ephemeroptera) in the area of small hydrological structures, in the streams of the Kamienica Nawojowska river basin (the Sądeckie Beskids, Poland). Ekológia (Bratislava), Vol. 35, No. 4, p. 320-339, 2016.

Anthropogenic modification of abiotic factor in turn influencez biotic communities. The aim of this study was to characterise clusters of mayflies in selected streams of Kamienica Nawojowska river basin in conjunction with small, lateral hydrological structures that have been built in this area. There was an attempt to determine whether and to what extent small lateral hydrological structures affect larvae of mayflies in the examined mountain streams. An analysis of the taxonomic composition of mayfly clusters in the examined stream sections was carried out. For this purpose, the author described the taxonomic wealth, variation in the density of organisms, the domination structure within taxonomic groups and trophic functional groups, taxonomic variation (based on the Shannon-Winner factor), constancy of occurrence (according to the Szujecki formula) as well as faunistic similarity (according to the Jaccard formula). An emphasis was also placed on the species included in the Red List of Vulnerable and Endangered Species in Poland (2002). The obtained results indicate a high taxonomic richness and a large diversity of mayfly fauna on the examined stream sections. There were no significant differences, however, in this aspect between posts situated upstream and downstream from the hydrological structures. The formation of clusters was influenced not so much by small hydrological structures as by other abiotic factors such as the nature of the bottom substrate, the way in which the basin is used, the location of a particular post on a particular watercourse section as well as other anthropogenic activities (e.g. those related to forest management). A comparison of the obtained data with the results of the research conducted before the completion of major regulatory works in Kamienica Nawojowska river basin showed that the mayfly fauna had preserved a large taxonomic richness, although some changes had occurred in the structure of the clusters. However, further research related to this issue is needed, especially in other river basins of the Beskids.
\end{abstract}

Key words: Ephemeroptera, macroinvertebrates, mountain streams, stream regulation, hydrological structures.

\section{Introduction}

Watercourses are one of the most intensively exploited ecosystems. Economic use of watercourses is often associated with anthropogenic transformations of the aquatic environment, 
which are a result of, among others, regulatory procedures and hydrological structures. It also refers to watercourses in mountainous areas (Niechwiej, 2015). Both the watercourse and the river basin are subject to a variety of hydromorphological processes. The material transported by water over the watercourse is called debris. The source of the debris, apart from denudation processes in the river basin, is channel erosion. It appears when the river transports less debris than allowed by the energy of the flowing water. Then this energy is redirected and contributes to the deepening and widening of the channel. The result of this is lateral, bottom and vertical erosion. This erosion is supposed to be prevented by hydrological structures (e.g. river bars, drop hydraulic structures and anti-debris dams; Radecki-Pawlik, 2012). They hamper the migration of aquatic organisms and cause depletion of the existing biocenoses (Wyżga et al., 2008).

The influence of anthropogenic factors on the biocenose of flowing water is multidirectional, which results from the impact of, among other things, the volume and velocity of water flow (Poff, Zimmerman, 2010), debris transport and bottom/channel shape (Wyżga et al., 2011), as well as the presence of natural and artificial obstacles (Kajak, 1992). Changes in abiotic and anthropogenic factors, caused by the presence of hydrological structures, affect in various ways individual hydrobiont groupings. Hydromorphological changes in a regulated watercourse usually cause species depletion in a particular biocenose (Dukowska, Grzybkowska, 2007; Kukuła, Bylak, 2011). The presence of lateral hydrological structures, even those of relatively small sizes, is important in the context of some benthic invertebrates travelling upstream (Błachuta et al., 2011). Such trips are usually undertaken by invertebrates of bigger sizes. It also concerns the larvae of some insects (e.g. caddis flies; MazurkiewiczBoroń, Starmach, 2009) and mayflies (cited by Allan, 1998) and is connected with their life cycles. By changing the volume and velocity of water flow, the presence of hydrological structures affects the way invertebrates drift (Brittain, Eikeland, 1988).

\section{The area of research and methods}

The research was conducted on the territory of The Kamienica Nawojowska river basin. The basin is located in the Carpathian region, which is characterised by significant rainfall and high surface runoff. The Kamienica Nawojowska River is a right-bank tributary of the Dunajec. The length of the river is $33.079 \mathrm{~km}$ (The Regional Water Management in Cracow 2010 - RWM Cracow 2010). It is a watercourse of the third category. The Kamienica Nawojowska river has its source on the north-eastern slope of the Przysłop Mountain, in Roztoka Wielka, and flows into te Dunajec in Nowy Sącz. The Kamienica Nawojowska river basin is an example of a medium-sized river basin of Beskids. The river basin can be divided into 21 watercourses, which belong to the $4^{\text {th }}$ to $7^{\text {th }}$ category (RWM Cracow). The research focused on three watercourses: Kryściów, Łabowczański Potok and Homerka (Fig. 1). These are watercourses of the $4^{\text {th }}$ category, left-bank tributaries of the Kamienica Nawojowska. They have deeply incised valleys, which are typical for the area of the Sądeckie Beskids. For the purposes of this study, the author has introduced the term 'facility' to describe lateral hydrological structures in the flow of the watercourse within which the fieldwork was conducted. The author designated five facilities on the examined watercourses: one on the Kryściów stream (Nowa Wieś - facility N), two on the Łabowczański Potok (Łabowiec - facility L, Łabowa - facility B) and two on the Homerka (Homrzyska - facility H, Frycowa - facility F). On each facility, the author set up three posts in the longitudinal profile of the watercourse. The location of each post was as follows:

- $\quad$ Type 1 post, around $20 \mathrm{~m}$ upstream from the hydrological structures.

- $\quad$ Type 2 post, around 2-3 m downstream from the hydrological structures, depending on the size of the structure, as well as the presence and size of erosion potholes.

- $\quad$ Type 3 post, around $20 \mathrm{~m}$ downstream from type 2 post. 


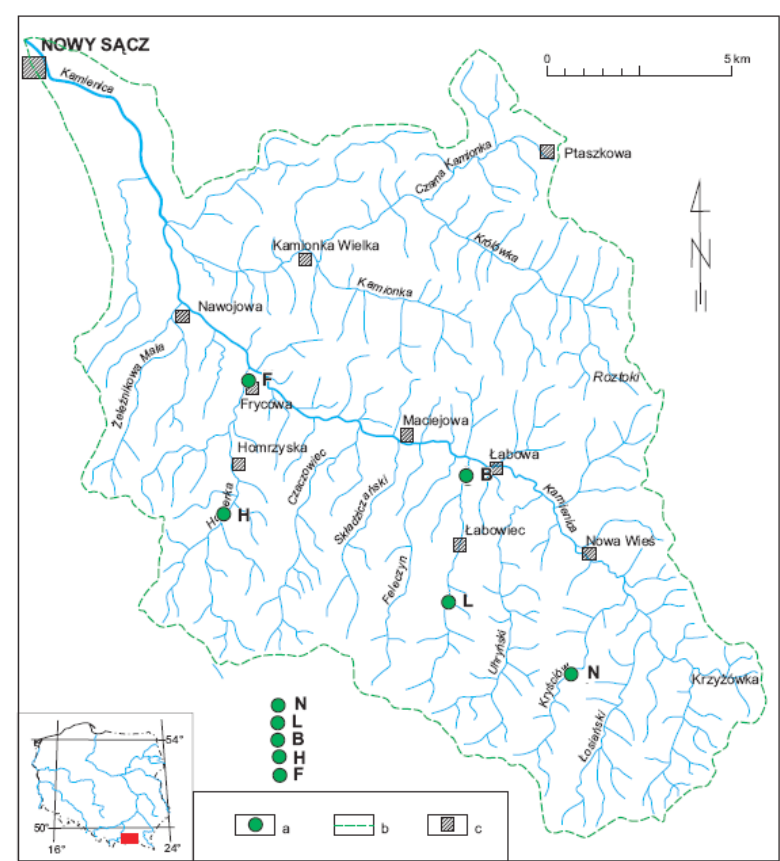

Fig. 1. Distribution of research facilities (a) in the Kamienica Nawojowska river basin, (b) with the map of localities, (c) symbols representing facilities were explained in the text (cited by Niechwiej 2013, according to RWM Cracow).
The study was conducted in the years 2010 and 2011 and consisted in collecting samples of benthic fauna six times: March, May, June, August, September and November. The dates were adapted both to the variable hydrological regime of the surveyed watercourses as well as to the life cycle of organisms, so as to demonstrate the presence of representatives of the largest possible number of mayfly taxons. In the field, the author measured each time basic hydrological and morphological parameters of watercourses, which was accompanied by a description of habitat characteristics as well as measurement of temperature and selected physical and chemical parameters. He measured the width and depth of watercourses in selected sections (Table 1). The flow rate measurement was made with the use of the float level indicator (Bajkiewicz-Grabowska et al., 1993). The degree of shading was determined on the basis of the visual analysis of water surface, an area of approximately $2 \mathrm{~m}^{2}$ (Plotnikoff, Wiseman, 2001). There was also a visual assessment of the degree of coverage of the bottom by periphyton. Each time, the author measured the physical parameters of water: temperature, electronic conductivity, oxygen saturation level and $\mathrm{pH}$.

In order to collect samples of benthic fauna, the author used the method called multi-habitat sampling (MHS), thus ensuring standard analytical procedures, in accordance with the Water Framework Directive. In the laboratory, the samples were sorted out, and the larvae of mayflies were preserved with $70 \%$ ethanol. The characterisation of benthic fauna groups was based on elementary biocenotic parameters such as the number of taxa, diversity of species (Shannon-Wiener index), domination structure and constancy of occurrence (Szujecki formula). The fauna similarity was analysed by the Jaccard formula. The author also determined the proportional share of each nutritional guild (trophic functional groups).

\section{Results}

The surveyed streams were not significantly different in terms of basic physical and chemical parameters of water. The values of the analysed parameters (temperature, $\mathrm{pH}$, electric conductivity, oxygen content) were similar for all sections of watercourses with hydro-technical facilities (Table 2). In addition, they showed only minor variations on an annual basis, with the exception of the temperature.

Water of the tested sections of streams was characterised by very good aerobic conditions, alkaline reaction and low salinity, as reflected by electric conductivity values, which reached a maximum value of $331 \mu \mathrm{Scm}^{-1}$. The water in those streams was cool. Its highest temperature in the summer season ranged from 10.5 to $12.5^{\circ} \mathrm{C}$. Furthermore, it was characterised by a low content of biogenic substances (Table 3 ). 
$\mathrm{T}$ a b l e 1. Characterisation of watercourses in selected sections.

\begin{tabular}{|c|c|c|c|c|c|c|c|c|}
\hline Stream & Facilities & Month & $\begin{array}{c}\text { Average } \\
\text { depth } \\
{[\mathbf{m}]}\end{array}$ & $\begin{array}{c}\text { Average } \\
\text { width } \\
\text { mainstream } \\
{[\mathbf{m}]}\end{array}$ & $\begin{array}{c}\text { Flow } \\
\text { rate } \\
\text { ranges } \\
{[\mathrm{m} / \mathrm{s}]}\end{array}$ & $\begin{array}{c}\text { Average } \\
\text { shade } \\
{[\%]}\end{array}$ & $\begin{array}{c}\text { Degree of } \\
\text { coverage of } \\
\text { the substrate } \\
\text { by CPOM } \\
{[\%]}\end{array}$ & $\begin{array}{c}\text { Degree of } \\
\text { coverage of } \\
\text { the substrate } \\
\text { by peryphyton } \\
{[\%]}\end{array}$ \\
\hline \multirow{6}{*}{ 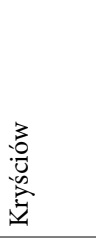 } & \multirow{6}{*}{ 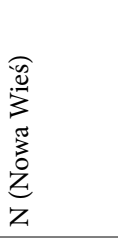 } & march & 0.20 & 2.0 & $0.2-0.4$ & 25 & 30 & $<5$ \\
\hline & & may & 0.25 & 2.5 & 0.4-0.6 & 25 & $<5$ & 5 \\
\hline & & june & 0.15 & 1.5 & $0.2-0.4$ & 60 & 15 & 50 \\
\hline & & august & 0.15 & 1.5 & $0.2-0.4$ & 60 & 15 & 40 \\
\hline & & september & 0.15 & 1.5 & $0.1-0.3$ & 40 & 30 & 25 \\
\hline & & november & 0.15 & 1.5 & $0.1-0.3$ & 30 & 50 & 15 \\
\hline \multirow{12}{*}{ 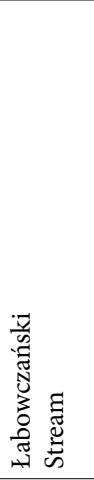 } & \multirow{6}{*}{ 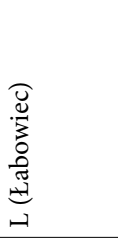 } & march & 0.30 & 3.5 & $0.3-0.5$ & 5 & $<5$ & $<5$ \\
\hline & & may & 0.30 & 4.0 & 0.4-0.6 & 10 & 10 & 5 \\
\hline & & june & 0.20 & 3.5 & $0.3-0.5$ & 70 & 15 & 90 \\
\hline & & august & 0.20 & 3.5 & $0.3-0.5$ & 70 & 15 & 80 \\
\hline & & september & 0.25 & 3.5 & $0.3-0.5$ & 30 & 20 & 60 \\
\hline & & november & 0.20 & 3.0 & $0.2-0.4$ & 15 & 25 & 25 \\
\hline & \multirow{6}{*}{ 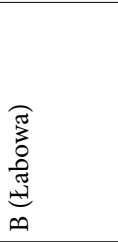 } & march & 0.35 & 3.5 & 0.7-0.9 & 0 & 10 & $<5$ \\
\hline & & may & 0.40 & 4.0 & $0.9-1.1$ & 5 & $<5$ & 5 \\
\hline & & june & 0.30 & 3.5 & $0.6-0.8$ & 10 & $<5$ & 90 \\
\hline & & august & 0.30 & 3.5 & $0.6-0.8$ & 10 & 10 & 80 \\
\hline & & september & 0.30 & 3.5 & $0.6-0.8$ & 5 & 10 & 60 \\
\hline & & november & 0.30 & 3.0 & 0.4-0.6 & 5 & 40 & 40 \\
\hline \multirow{12}{*}{ 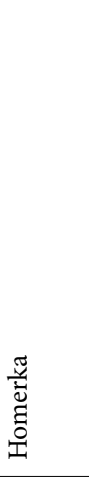 } & \multirow{6}{*}{ 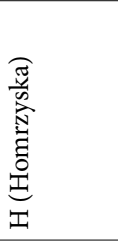 } & march & 0.25 & 3.5 & $0.7-0.9$ & 30 & 20 & 5 \\
\hline & & may & 0.30 & 4.0 & $0.9-1.1$ & 40 & $<5$ & 10 \\
\hline & & june & 0.20 & 3.5 & $0.6-0.8$ & 80 & $<5$ & 90 \\
\hline & & august & 0.20 & 3.5 & $0.7-0.9$ & 80 & 15 & 80 \\
\hline & & september & 0.20 & 3.5 & 0.7-0.9 & 50 & 20 & 70 \\
\hline & & november & 0.15 & 3.0 & $0.5-0.7$ & 30 & 25 & 60 \\
\hline & \multirow{6}{*}{ 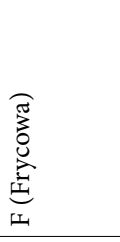 } & march & 0.35 & 4.0 & $0.7-0.9$ & 0 & 10 & 5 \\
\hline & & may & 0.40 & 4.5 & $1.1-1.3$ & 10 & $<5$ & 10 \\
\hline & & june & 0.30 & 4.0 & $0.7-0.9$ & 30 & 10 & 90 \\
\hline & & august & 0.30 & 4.0 & $0.6-0.8$ & 30 & 15 & 80 \\
\hline & & september & 0.35 & 4.0 & $0.6-0.8$ & 15 & 15 & 50 \\
\hline & & november & 0.30 & 3.5 & $0.5-0.7$ & 10 & 20 & 40 \\
\hline
\end{tabular}

All values of the analysed compounds of nitrogen and phosphorus fell within the range of waters of the first class of purity, according to the Regulation of the Ministry of the Environment of 9 November 2011 on the classification system of surface waters and environmental quality standards for priority substances (Journal of Laws, No. 257, item 1545). Among them, the lowest amount of biogenic substances was recorded in the Kryściów creek, flowing through a wooded area and deprived of any buildings. Slightly higher content was shown in the Łabowczański 
$\mathrm{T}$ a b l e 2. Values of basic physical and chemical parameters of water at particular hydro-technical facilities

\begin{tabular}{|l|c|c|c|c|c|}
\hline Stream & Facilities & $\begin{array}{c}\text { Temperature } \\
\text { min.-max. }\left[{ }^{\circ} \mathbf{C}\right]\end{array}$ & $\begin{array}{c}\text { Degree of oxygen } \\
\text { saturation }[\%]\end{array}$ & $\begin{array}{c}\text { Electrolic conductivity } \\
{\left[\boldsymbol{\mu} \mathbf{s c m}^{-1}\right]}\end{array}$ & $\mathbf{p H}$ \\
\hline Kryściów & $\mathrm{N}$ & $2.0-10.5$ & $93.8 \pm 1.7$ & $278 \pm 31$ & $8.10-8.34$ \\
\hline $\begin{array}{l}\text { Łabowczański } \\
\text { Stream }\end{array}$ & $\mathrm{L}$ & $2.3-11.4$ & $94.3 \pm 1.6$ & $267 \pm 33$ & $8.06-8.28$ \\
\cline { 2 - 6 } & $\mathrm{B}$ & $2.5-12.2$ & $95.7 \pm 1.5$ & $331 \pm 32$ & $8.02-8.23$ \\
\hline \multirow{2}{*}{ Homerka } & $\mathrm{H}$ & $2.1-10.8$ & $97.0 \pm 1.6$ & $244 \pm 34$ & $8.36-8.89$ \\
\cline { 2 - 6 } & $\mathrm{F}$ & $2.6-12.5$ & $97.8 \pm 1.6$ & $302 \pm 33$ & $8.32-8.78$ \\
\hline
\end{tabular}

$\mathrm{T} \mathrm{a} \mathrm{b} \mathrm{l} \mathrm{e} \mathrm{3.} \mathrm{The} \mathrm{level} \mathrm{of} \mathrm{biogenic} \mathrm{substances} \mathrm{in} \mathrm{the} \mathrm{water} \mathrm{at} \mathrm{particular} \mathrm{hydro-technical} \mathrm{facilities.}$

\begin{tabular}{|l|c|c|c|c|c|}
\hline Stream & Facilities & $\begin{array}{c}\text { Nitrate nitrogen } \\
{\left[\mathbf{m g N O}_{\mathbf{3}} \mathbf{d m}^{-3}\right]}\end{array}$ & $\begin{array}{c}\text { Ammonia nitrogen } \\
{\left[\mathbf{m g N H}_{\mathbf{4}} \mathbf{d m}^{-3}\right]}\end{array}$ & $\begin{array}{c}\text { Total phosphorus } \\
{\left[\mathbf{m g P d m}^{-3}\right]}\end{array}$ & $\begin{array}{c}\text { Phosphates } \\
{\left[\mathbf{m g P O}_{\mathbf{4}} \mathbf{d m}^{-3}\right]}\end{array}$ \\
\hline Kryściów & $\mathrm{N}$ & 0.380 & 0.051 & $<0.020$ & $<0.031$ \\
\hline \multirow{2}{*}{$\begin{array}{l}\text { Labowczański } \\
\text { Stream }\end{array}$} & $\mathrm{L}$ & 0.439 & 0.083 & $<0.020$ & $<0.031$ \\
\cline { 2 - 6 } & $\mathrm{B}$ & 1.010 & 0.071 & 0.032 & 0.087 \\
\hline \multirow{2}{*}{ Homerka } & $\mathrm{H}$ & 0.633 & 0.068 & 0.037 & 0.093 \\
\cline { 2 - 6 } & $\mathrm{F}$ & 0.793 & 0.134 & 0.027 & 0.069 \\
\hline
\end{tabular}

and Homerka streams, which flowed mainly through rural areas. However, only the content of nitrate nitrogen tended to increase with the flow of the watercourse in case of both streams.

\section{General characterisation of mayfly groupings}

Mayfly groupings on the tested sections of streams were characterised by high taxonomic richness. In total, the author found 30 species of six families, including eight species of the Heptageniidae, 10 of Baetidae, four of Leptophlebiidae, four of Ephemerellidae and one of Caenidae (Table 4).

The greatest taxonomic diversity of mayflies was found in the Homerka stream in its lower reaches (the posts of the facility F in Frycowa) - 23 species were found at the post F3.

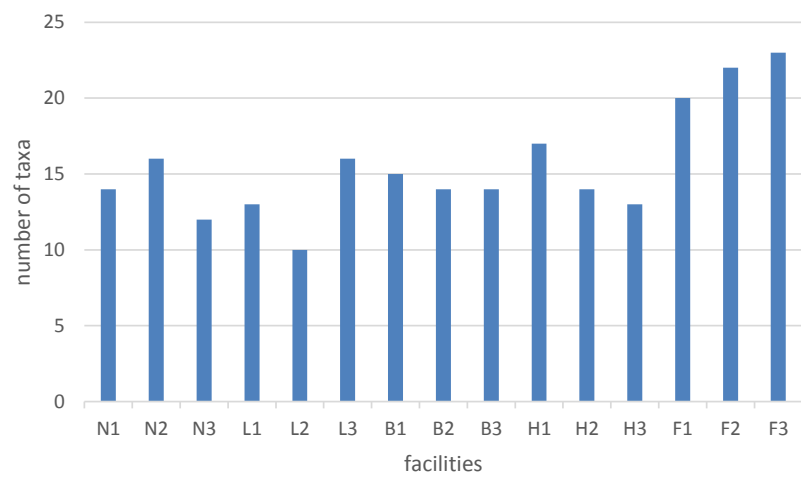

Fig. 2. Taxonomic diversity of mayflies at the surveyed posts. The lowest number of taxa, 10 , was recorded at the post L2 in Łabowiec (the Łabowczański stream). There were no significant differences in the taxonomic diversity of groupings between facilities in Nowa Wieś $(\mathrm{N})$, Łabowa $(\mathrm{N})$ and Homrzyska (H) (Fig. 2).

There were no clear patterns in the differentiation of the number of species between posts of three types, 
$\mathrm{T} \mathrm{a} \mathrm{b}$ l e 4 . Numbers of larvae at particular posts.

\begin{tabular}{|c|c|c|c|c|c|c|c|c|c|c|c|c|c|c|c|}
\hline & N1 & N2 & N3 & L1 & L2 & L3 & B1 & B2 & B3 & H1 & $\mathrm{H} 2$ & H3 & F1 & F2 & F3 \\
\hline \multicolumn{16}{|l|}{ Heptageniidae } \\
\hline Rhithrogena semicolorata & 156 & 52 & 33 & 150 & 99 & 195 & 159 & 135 & 90 & 123 & 137 & 159 & 132 & 96 & 218 \\
\hline Rhithrogena iridina & 249 & 78 & 15 & 168 & 114 & 249 & 150 & 153 & 129 & 133 & 105 & 162 & 180 & 117 & 273 \\
\hline Rhithrogena puytoraci & 12 & 18 & 0 & 6 & 0 & 15 & 3 & 9 & 9 & 9 & 0 & 15 & 6 & 6 & 3 \\
\hline Ecdyonurus venosus & 30 & 12 & 6 & 0 & 12 & 24 & 39 & 27 & 18 & 12 & 6 & 12 & 42 & 21 & 63 \\
\hline Ecdyonurus torrentis & 21 & 21 & 18 & 21 & 93 & 51 & 120 & 66 & 93 & 33 & 15 & 18 & 102 & 195 & 66 \\
\hline Ecdyonurus subalpinus & 3 & 0 & 0 & 0 & 0 & 0 & 0 & 0 & 0 & 0 & 3 & 0 & 0 & 3 & 0 \\
\hline Ecdynurus submontanus & 3 & 0 & 0 & 6 & 3 & 9 & 3 & 6 & 21 & 15 & 0 & 0 & 15 & 39 & 51 \\
\hline Epeorus assimilis & 195 & 87 & 3 & 54 & 39 & 111 & 63 & 123 & 54 & 173 & 81 & 108 & 21 & 66 & 12 \\
\hline \multicolumn{16}{|l|}{ Baetidae } \\
\hline Baetis rhodani & 15 & 52 & 9 & 24 & 54 & 9 & 234 & 186 & 114 & 72 & 90 & 96 & 180 & 177 & 234 \\
\hline Baetis lutheri & 0 & 0 & 0 & 3 & 0 & 3 & 15 & 12 & 9 & 0 & 0 & 0 & 9 & 3 & 3 \\
\hline Baetis scambus & 0 & 9 & 0 & 0 & 0 & 3 & 3 & 0 & 0 & 12 & 0 & 12 & 9 & 12 & 12 \\
\hline Baetis fuscatus & 0 & 18 & 9 & 6 & 0 & 6 & 3 & 0 & 0 & 36 & 18 & 18 & 6 & 9 & 6 \\
\hline Baetis alpinus & 0 & 3 & 0 & 0 & 3 & 12 & 0 & 0 & 12 & 36 & 24 & 21 & 18 & 12 & 6 \\
\hline Baetis muticus & 0 & 0 & 0 & 0 & 0 & 0 & 0 & 3 & 0 & 0 & 0 & 0 & 0 & 3 & 12 \\
\hline Baetis melanonyx & 36 & 3 & 6 & 0 & 6 & 15 & 30 & 6 & 0 & 21 & 9 & 27 & 30 & 18 & 102 \\
\hline Baetis niger & 0 & 0 & 0 & 0 & 0 & 0 & 0 & 0 & 0 & 0 & 1 & 0 & 0 & 0 & 0 \\
\hline Procleon pulchrum & 0 & 3 & 0 & 0 & 0 & 0 & 0 & 0 & 3 & 0 & 0 & 0 & 3 & 24 & 0 \\
\hline Centroptilum luteolum & 0 & 0 & 0 & 6 & 0 & 0 & 0 & 0 & 0 & 0 & 0 & 0 & 0 & 0 & 3 \\
\hline \multicolumn{16}{|l|}{ Leptophlebiidae } \\
\hline Paraleptophlebia cincta & 9 & 3 & 0 & 0 & 0 & 0 & 0 & 0 & 6 & 21 & 63 & 81 & 12 & 24 & 36 \\
\hline Paraleptophlebia submarginata & 6 & 6 & 18 & 12 & 21 & 6 & 21 & 6 & 24 & 57 & 51 & 63 & 42 & 57 & 72 \\
\hline Habrophlebia lauta & 0 & 0 & 0 & 0 & 0 & 0 & 0 & 0 & 0 & 0 & 0 & 0 & 0 & 3 & 3 \\
\hline Habrophlebia fusca & 0 & 0 & 0 & 0 & 0 & 0 & 0 & 0 & 0 & 0 & 0 & 0 & 0 & 0 & 3 \\
\hline \multicolumn{16}{|l|}{ Ephemerellidae } \\
\hline Seratella ignita & 0 & 6 & 0 & 6 & 0 & 9 & 39 & 9 & 30 & 3 & 0 & 0 & 9 & 21 & 3 \\
\hline Ephemerella notata & 0 & 33 & 12 & 0 & 0 & 0 & 0 & 0 & 0 & 0 & 0 & 0 & 3 & 6 & 0 \\
\hline Ephemerella mucronata & 0 & 0 & 0 & 0 & 0 & 0 & 0 & 0 & 0 & 0 & 0 & 0 & 18 & 0 & 0 \\
\hline Torleya mayor & 0 & 0 & 0 & 0 & 0 & 0 & 0 & 3 & 0 & 0 & 0 & 0 & 0 & 0 & 0 \\
\hline \multicolumn{16}{|l|}{ Ephemeridae } \\
\hline Ephemera danica & 6 & 0 & 12 & 3 & 0 & 3 & 9 & 0 & 0 & 3 & 0 & 0 & 6 & 0 & 3 \\
\hline Ephemera vulgata & 9 & 0 & 6 & 0 & 0 & 0 & 0 & 0 & 0 & 12 & 3 & 0 & 0 & 0 & 6 \\
\hline Ephemera lineata & 0 & 0 & 0 & 0 & 0 & 0 & 0 & 0 & 0 & 0 & 0 & 0 & 0 & 0 & 1 \\
\hline \multicolumn{16}{|l|}{ Caenidae } \\
\hline Caenis horaria & 0 & 0 & 0 & 0 & 0 & 0 & 0 & 0 & 0 & 0 & 0 & 0 & 0 & 3 & 0 \\
\hline
\end{tabular}

differently placed in relations to the hydrological structures. At the posts of type 2 , at the facilities $\mathrm{L}, \mathrm{B}$ and $\mathrm{H}$, the number of mayfly taxa was slightly lower than at the posts of type 1 (1 to 3 species), but it was not observed at other facilities. 


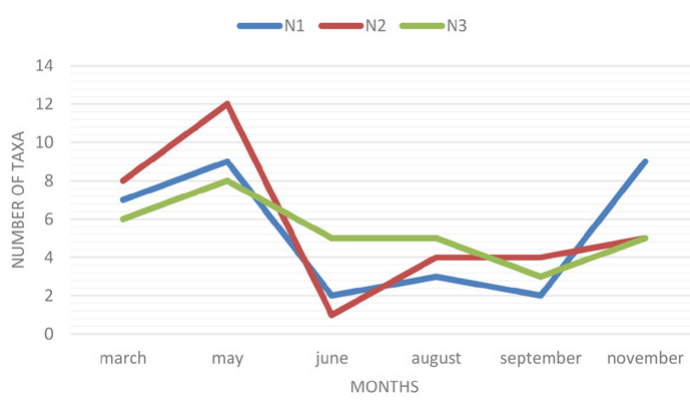

Fig. 3. The number of mayfly species at the posts N1-N3.

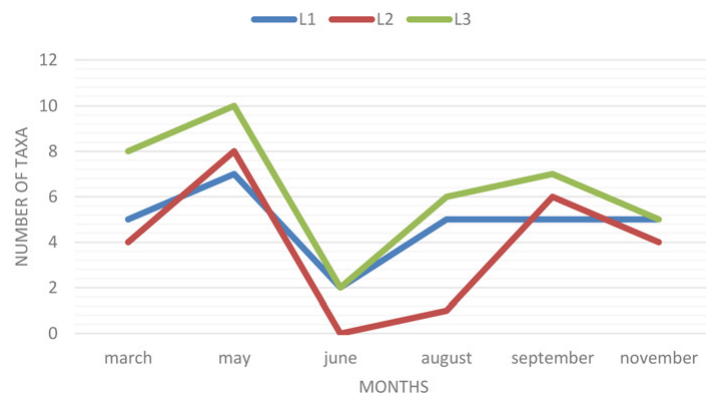

Fig. 4. The number of mayfly species at the posts L1-L3.

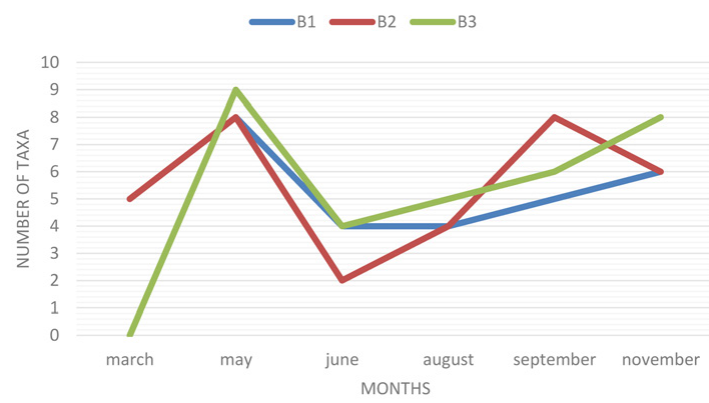

Fig. 5. The number of mayfly species at the posts B1-B3.

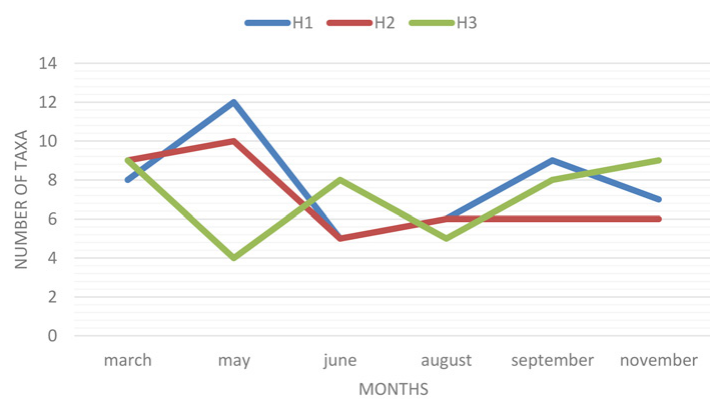

Fig. 6. The number of mayfly species at the posts $\mathrm{H} 1-\mathrm{H} 3$.
Variation the richness of taxonomic groupings in seasonal and spatial terms

Mayfly fauna inhabiting different sections of the streams was varied in terms of the number of taxa. The author observed a similar trend in all the groupings - the largest taxonomic diversity occurred in the spring, whereas its decline was observed during the summer. The beginning of autumn is usually the time when the number of taxa increases again (Figs 3-7).

A particular taxonomic richness of mayflies was observed in May. In this period, the number of species ranged from 4 (the post $\mathrm{H}$ ) to 15 (F3). This was influenced by a large number of taxa of the family Heptageniidae (Rhithrogena sp., Ecdyonurus sp., Epeorus sp.), as well as representatives of the genus Baetis sp. (Baetidae). Mayflies of the species Ephemerella (family Ephemerellidae) were observed only in May.

Taxonomic diversity plummeted in early summer (June), when no mayfly was noticed at the post L2 in Łabowiec. It was only in Homrzyska, the post located approximately $30 \mathrm{~m}$ downstream from the hydrological structures (H3) that the presence of eight species was recorded, five of which belonged to the genus Baetis. The post $\mathrm{H} 3$ on the Homerka creek stood out from the rest in terms of atypical variability of the number of taxa in this season - most of them were observed in March (9) and November (9), and the fewest were seen in May (only 4). 
Late summer and autumn was marked by re-growth of taxonomic diversity in mayfly groupings on the surveyed sections of streams (particularly in September). August was the period when the presence of larvae of Serratella ignita (Ephemerellidae) was recorded. Moreover, like in the spring, numerous taxa of the families Heptageniidae, Baetidae, as well as species Heptageniidae, Baetidae and Paraleptophlebia were observed. There were no significant differences in taxonomic diversity of mayfly groupings between types of posts 1 , 2 and 3, which could indicate a possible influence of hydrological structures.

Variability in the density of mayfly larvae in seasonal and spatial terms

The number of mayflies was subject to considerable fluctuations throughout the year on all the sections of the surveyed streams, leading to big changes in density. Changes in the density of mayfly larvae were often marked by large fluctuations. The highest density was observed in the Homerka stream, especially at the posts of the facility in Frycowa (F) (Figs. 8-12).

By analysing changes in the density of mayflies on the surveyed sections of the stream, it can be noted that they reached the largest numbers in spring (especially in May) and autumn (especially September). Most of them were species from the Heptageniidae family (Rhithrogena sp., Epeorus sp., to a smaller degree Ecdyonurus sp.) and from the Leptophlebidae family (Paraleptophlebia sp.). The period of summer (June-August) is marked by a distinct decline in the population of mayflies. Only species of the Baetidae family (Baetis rhodani, B. melanonyx) and Ephemerellidae family (Serratella ignita, which were numerous

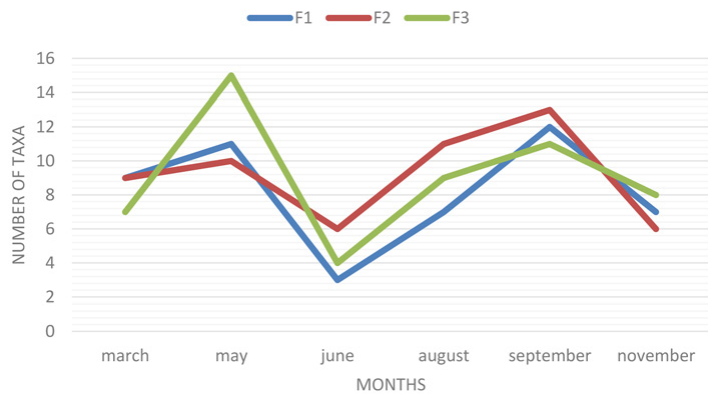

Fig. 7. The number of mayfly species at the posts F1-F3.

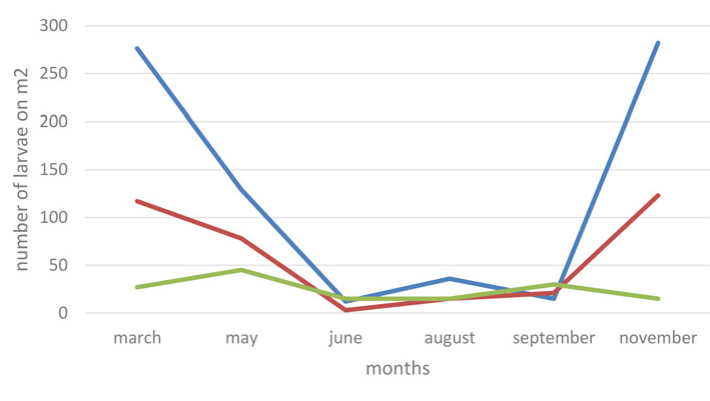
the facility $\mathrm{N}$.

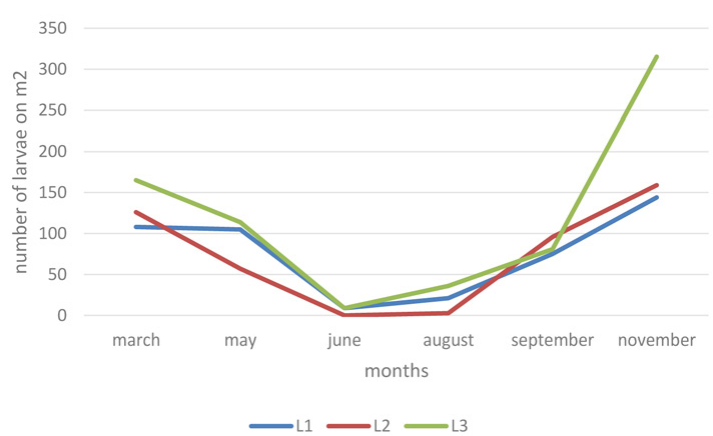

Fig. 9. Changes in the density of mayfly larvae at the posts $1-3$ of the facility L.
Fig. 8. Changes in the density of mayfly larvae at the posts $1-3$ of 


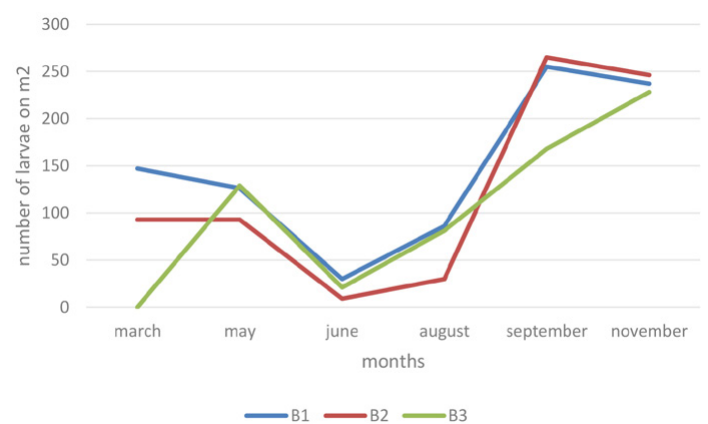

Fig. 10. Changes in the density of mayfly larvae at the posts $1-3$ of the facility B.

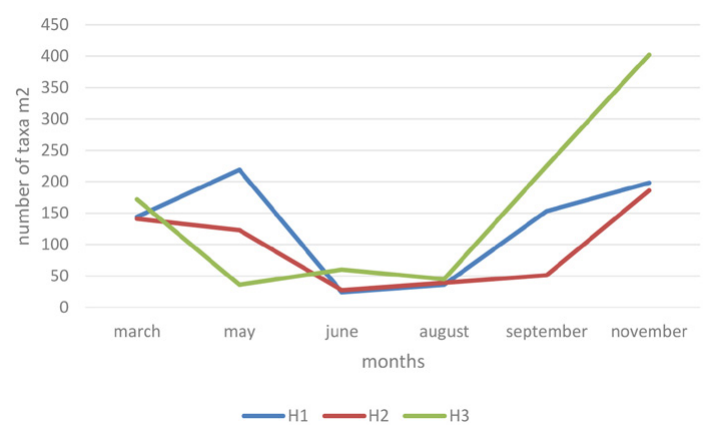

Fig. 11. Changes in the density of mayfly larvae at the posts $1-3$ of the facility $\mathrm{H}$.

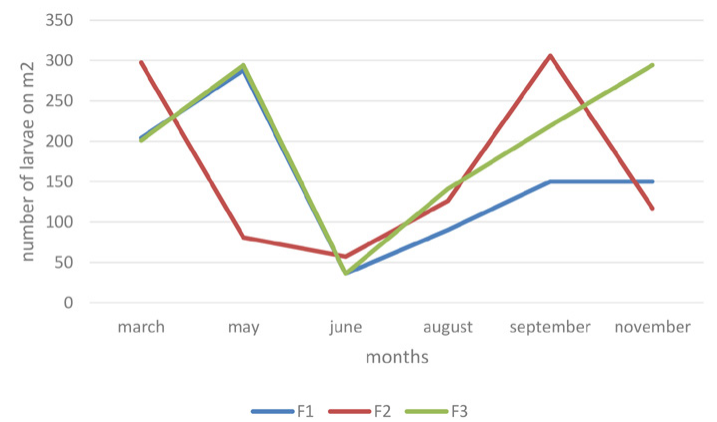

Fig. 12. Changes in the density of mayfly larvae at the posts 1-3 of the facility $\mathrm{F}$. tidae and Leptophlebiidae. At all the posts, the dominant species were those of the genus Rhithrogena. These were mostly Epeorus assimilis (they were not dominant at, for example, posts of the facility in Frycowa) and Baetis rhodani. Ecdyonurus torrentis was dominant in the middle course of the Łabowczański Potok stream (the facility in Łabowiec) and the lower in August at the sections with facilities $\mathrm{B}$ and $\mathrm{F}$ ) formed more numerous groupings (Table 3 ).

It is hard to notice any clear trends of differentation in the number of larvae between particular types of posts (1,2 and 3). Small numbers of larvae and small variation in their density over the year were demonstrated at the post N3 in Nowa Wieś (the Kryściów stream). In the absence of similar patterns at the other facilities, it is difficult to believe that it was the result of the position of this post in relation to hydrological structures. However, the number of mayflies of the Baetidae family rose proportionately to the size of the stream (the Homerka stream) and the distance from the source (facilities in Łabowa and Frycowa) (Table 3).

\section{The structure of domination}

During the year, it could be observed that a few species distinctly dominated the studied clusters of mayflies. Those species reached the eudominanta status (more than 10\% of the total number of specimens) at particular posts (Fig. 13) or in particular months (Fig. 14). In total, there were 11 species. In the following chart, the term 'domination' represents the share of eudominanta.

The structure of taxonomic of the families Heptageniidae, Baegroupings was dominated by species

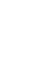




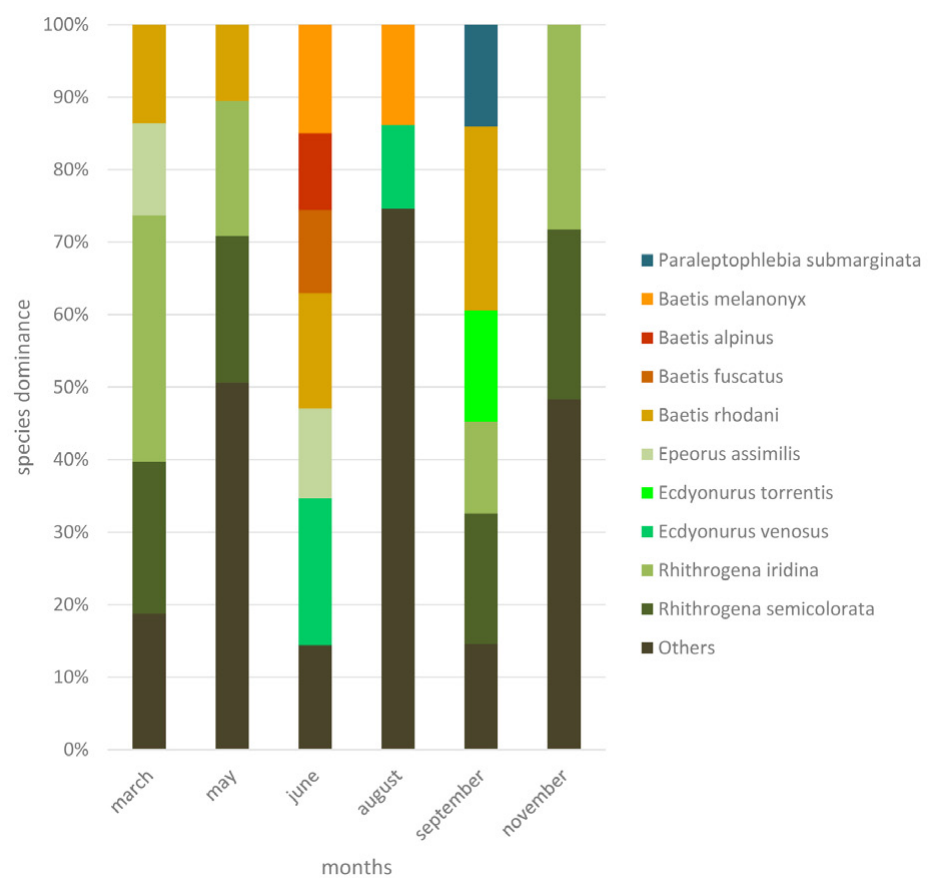

Fig. 13. The share of dominants at particular posts during the year.

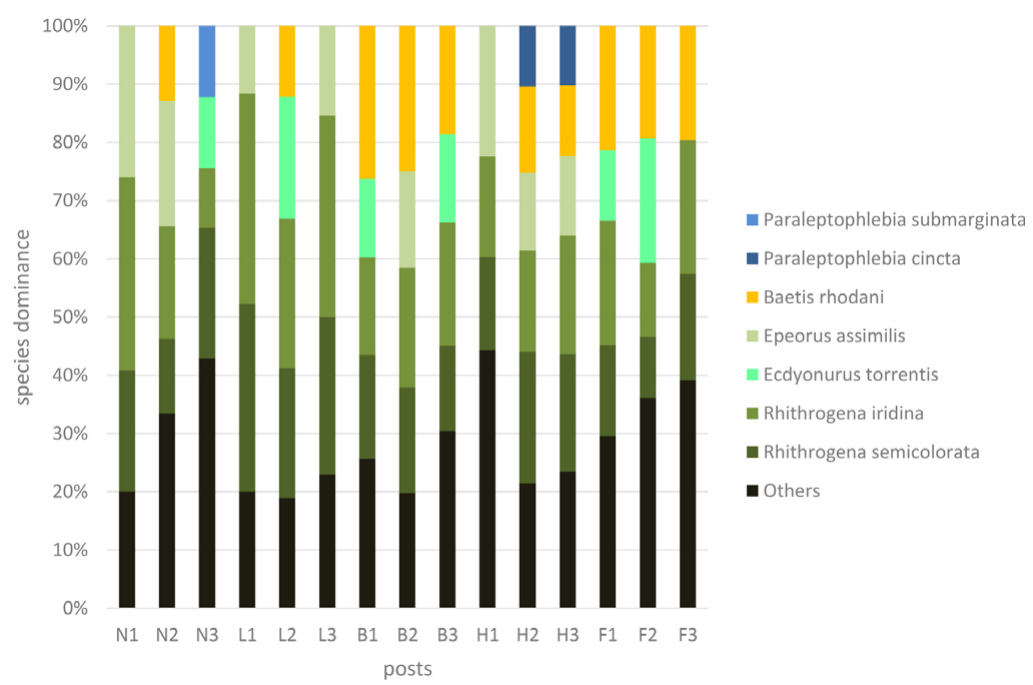

Fig. 14. The share of dominants in particular months (at all posts). 
reaches of the Łabowczański Potok and Homerka (facilities in Łabowa and Frycowa). Species of the genus Paraleptophlebia were dominant at the posts located downstream from the hydrological structures, on the sections of streams where the basin covered forested areas (facilities in Nowa Wieś and Homrzyska). In the spring (March-May), the groupings of mayflies were dominated by the species of the Heptageniidae family mentioned above, similarly in November (Fig. 14). The dominant species in the spring was also Baetis rhodani. In the summer and early autumn (September), the taxonomic structure of dominants was more diverse, despite the general decline in the diversity of taxonomic groupings (Figs 3-7). In June and August, no representatives of Rhithrogena species were observed. However, the dominant species were the Ecdyonurus venosus and other species of the genus Baetis. In September also, the species Paraleptophlebia submarginata were observed. The posts of the facilities situated in the lower reaches of the streams (Labowa and Frycowa) were characterised by the dominance of the Serratella ignita larvae (Table 4). The stability of the presence of dominant species varied during the year. The factor of stability according to the Szujecki formula accepted the values 1-100 for different taxa (Table 5).

T a b l e 5. The factor of stability of dominant occurrence.

\begin{tabular}{|l|c|c|c|c|c|c|}
\hline & march & may & june & august & september & november \\
\hline Rhihrogena semicolorata & 93 & 93 & 13 & 13 & 100 & 100 \\
\hline Rh. iridina & 93 & 93 & 20 & 20 & 100 & 100 \\
\hline Ecdyonurus torrentis & 73 & 80 & 20 & 27 & 80 & 67 \\
\hline E. venosus & 27 & 60 & 53 & 60 & 40 & 13 \\
\hline Epeorus assimilis & 73 & 73 & 40 & 40 & 47 & 93 \\
\hline Baetis rhodani & 87 & 67 & 60 & 40 & 73 & 73 \\
\hline B. alpinus & 13 & 33 & 20 & 7 & 27 & 0 \\
\hline B. fuscatus & 33 & 47 & 33 & 27 & 7 & 7 \\
\hline B. melanonyx & 0 & 27 & 60 & 67 & 40 & 0 \\
\hline Paraleptophlebia cincta & 40 & 27 & 0 & 0 & 40 & 47 \\
\hline P. submarginata & 27 & 93 & 0 & 7 & 53 & 47 \\
\hline
\end{tabular}

Representatives of dominant species of the Heptageniidae family (with the exception of Ecdyonurus venosus) were present at the majority of posts in the spring and autumn period (Rhithrogena sp. was even observed at $100 \%$ of the posts in the autumn). It was the same in the case of Baetis rhodani mayfly. Other species of dominants from the Baetidae family were found at a smaller number of posts. However, the factor values showed smaller amplitude fluctuations during the year. The larvae of the Paraleptophlebia sp. were noticed mainly in the spring and autumn; in May the P. submarginata species occurred at $93 \%$ of posts.

\section{Taxonomic diversity}

The taxonomic diversity of the mayfly fauna at the surveyed posts was quite large, as evidenced by maximum and average values of the Shannon-Wiener index, recorded during the year. At the same time, diversity of particular groups was characterised by considerable vari- 
T a b l e 6. Values of the Shannon-Wiener index for mayfly groupings at the surveyed posts.

\begin{tabular}{|l|c|c|c|c|}
\hline Facilities & Posts & \multicolumn{3}{|c|}{ Values } \\
\hline \multirow{3}{*}{ N } & & Min. & Max. & Average value \\
\cline { 2 - 5 } & N1 & 0.56 & 1.73 & $1.11 \pm 0.53$ \\
\cline { 2 - 5 } & N2 & 0 & 2.32 & $1.38 \pm 0.78$ \\
\hline \multirow{3}{*}{ L } & L1 & 0.8 & 1.87 & $1.53 \pm 0.37$ \\
\cline { 2 - 5 } & L2 & 0.64 & 1.66 & $1.28 \pm 0.37$ \\
\cline { 2 - 5 } & L3 & 0 & 1.81 & $0.97 \pm 0.88$ \\
\hline \multirow{3}{*}{ B } & B1 & 0.64 & 2.14 & $1.41 \pm 0.50$ \\
\cline { 2 - 5 } & B2 & 1.17 & 1.63 & $1.41 \pm 0.19$ \\
\cline { 2 - 5 } & B3 & 0.64 & 1.78 & $1.39 \pm 0.40$ \\
\hline \multirow{3}{*}{ H } & H1 & 1.49 & 2.02 & $1.25 \pm 0.72$ \\
\cline { 2 - 5 } & H2 & 1.46 & 2.21 & $1.73 \pm 0.30$ \\
\cline { 2 - 5 } & H3 & 1.37 & 1.89 & $1.64 \pm 0.19$ \\
\hline \multirow{3}{*}{ F } & F1 & 0.92 & 1.90 & $1.57 \pm 0.29$ \\
\cline { 2 - 5 } & F2 & 1.46 & 2.12 & $1.74 \pm 0.20$ \\
\cline { 2 - 5 } & F3 & 1.25 & 2.11 & $1.61 \pm 0.34$ \\
\hline
\end{tabular}

ability over the year (Table 6). Differences in the index values (min.-max.) raged from 0.43 (post $\mathrm{H} 2$ ) to 2.32 (post N2).

The lowest values of the Shannon-Wiener index were obtained in the summer season, the and lower values were also observed in spring and autumn. Differences in the index values between particular watercourses were not significant, whereas the greatest taxonomic diversity of mayfly fauna was recorded in clusters inhabiting the Homerka stream (average index values ranged from 1.57 to 1.74). It is difficult to distinguish patterns in the distribution of the Shannon-Wiener index values between posts of particular types (1,2 and 3).

\section{Trophic functional groups}

In mayfly groupings, there were representatives of various feeding guilds (trophic functional groups).

In the studies area, the different trophic groups represented the following families:

- Shredders: Leptophlebiidae,

- Scrapers: Heptageniidae,

- Collectors: Ephemerellidae, Caenidae, Ephemeridae and Baetidae.

The analysis of the structure of particular mayfly groupings did not show any significant differences in the percentage of distinguished trophic groups between types of posts (Fig. 15a-c).

The participation of scrapers in mayfly groupings at the surveyed types of posts was the largest - from 64\% (type2) to 70\% (type1). These were mainly Rhithrogena sp., Epeorus sp.and Ecdyonurus sp. Approximately one-fourth of the larvae were representatives of collectors - from $25 \%$ (type 1) to $28 \%$ (type 2). Among them, the most numerous were the larvae 


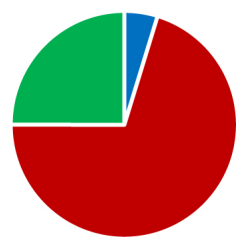

a). type 1

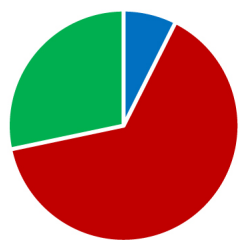

b). type 2

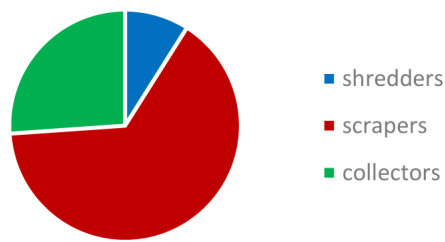

c). type 3

Fig.15a-c. Percentage of representatives of feeding guilds at particular posts.

of the family Baetidae, mainly Baetis rhodani, and in the summer also Serratella ignita from the family Ephemerellidae. The smallest group were the shredders - 5\% (type 1) and 9\% (type 3) - mainly representatives of the genus Paraleptophlebia.

\section{Faunistic similarity}

Mayfly fauna inhabiting the studied streams in the sections covering small lateral hydrological structures was characterised by a high degree of similarity in terms of composition and structure of clusters. To a large extent, it could result from the small basin of the Kamienica Nawojowska, and thus from similar abiotic features of the environment such as the nature of the ground, speed of water flow and physico-chemical properties of water (Tables 1 to 3 ). Cluster analysis showed that mayfly clusters developing directly downstream from hydrological structures (posts of the type 2) differed to certain degree from others, that is, those occurring upstream from the structures (type 1) and downstream, but at a greater distance (type 3) (Fig.16).

However, differences within the particular mayfly clusters were not significant. The numbers of species found on individual types of posts are approximately the same (Table 3). The posts of type 2 had a smaller number of Rhithrogena sp. and a larger number of Ecdyonurus sp. In addition, species such as Baetis niger, Torleya mayor and Caenis horaria were found only at posts situated downstream from hydrological structures. On the other hand, Centroptilum luteolum and

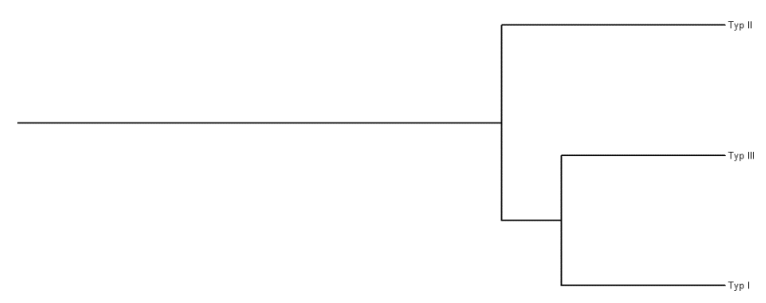

Fig. 16. Diagram of faunistic similarities by the type of posts.
Ephemera danica, whose presence was demonstrated at posts of type 1 and 3 , were not observed at posts of type 2 . The studied sections of streams revealed the presence of three species included on the Red List of Vulnerable and Endangered Species in Poland (2002). These were: Paraleptophlebia cincta, Ephemerella notata and Ephemera lineata. The last one is mentioned on the Red List as 'vulnerable species'. 


\section{Discussion}

The results of research connected with mayfly fauna conducted in the Kamienica Nawojowska river basin in the years 2010-2011 can be compared with similar tests carried out in the same area in the years 1964-1965 by Zaćwilichowska (1968). Taxonomic diversity of mayfly groupings demonstrated by the studies of the 1960s does not differ significantly from the taxonomic richness showed by present research.There are, however, some differences, in the taxonomic structure of groupings. In 2010-2011, during the period from June to September, mayflies were represented by numerous larvae of the family Baetidae, including Baetis melanonyx, B. rhodani and B. fuscatus. At the same time, in summer, those mayflies constituted only $10 \%$ of benthic fauna in the Łabowczański Potok (facility L) and the Homerka (facility $\mathrm{H})$. In addition, in September, mayflies from the genus Rhithrogena (Heptageniidae) reached the dominant status in the Kryściów stream. Meanwhile, Zaćwilichowska (1968) showed an overwhelming dominance in zoobenthos of the family Baetidae (mainly Baetis rhodani) in each of the three studied watercourses. Furthermore, she noted the presence Ecdyonurus helveticus and E. venosus (up to $10 \%$ of the benthic fauna) in the Łabowczański Potok, as well as the occurrence of Ephemerella ignita and Caenis macrura in the Homerka stream.

Mayfly fauna demonstrated in this study was similar in its taxonomic composition to groupings of watercourses in other Beskid river basins, e.g. the Gorce, the Pieniny and the Bieszczady Mountains (Zasępa et al., 2006; Kłonowska-Olejnik et al., 2012; KłonowskaOlejnik, Skalski, 2014). This concerns mainly mayflies that are common in this area, which is representative of the family Heptageniidae (genus Ecdyonurus, Rhithrogena, Epeorus), Baetidae (genus Baetis, Centroptilum) and Ephemerellidae (genus Serratella, Habrophlebia). In the above mentioned Beskid river basins, the family Leptophlebiidae was more often represented by Habroleptoides confusa larvae, whereas in the current studies the dominant genus was Paraleptophlebia. Many researchers have shown that the basic abiotic factors determining the taxonomic wealth of gropus of benthos in mountain watercourses are: the type and structure of the substrate, the speed and volume of flow, water temperature and its oxygenation, as well as the character of basin development (Hawkins, Sedella, 1981; Sandin, Johnson, 2004; Pedersen, Friberg, 2007). In the studied watercourses of the Kamienica Nawojowska river basin, those elements of the biotope developed in a similar way, influencing the formation of similar mayfly groupings. There was no evidence, therefore, of any significant differences in taxonomic diversity between groupings inhabiting the studied watercourses, but only some variation in their composition and structure. Dominant species were the litophilic ones and reobionts, which prefer fast flowing and well-oxygenated water, e.g. Epeorus sp., Ecdyonurus sp., Rhithrogena sp. There were also representatives of taxa of broader distribution and higher environmental tolerance, such as Baetis rhodani and Serratella ignita (Olsen, Watzin, 2009).

Within the tested facilities (N, L, B, F, H), the structure and grain size of the bottom substrate were similar - these were mainly stones and gravel, coarse particulate organic matter (CPOM), as well as sandy and silty deposits. Such a heteregenous structure of the bottom substrate resulted in a large variety of habitats, and this in turn influenced in a crucial way the taxonomic richness and diversity of benthic groupings. The grain size of the bottom as well 
as the presence of organic matter in the mineral substrate affects the density and distribution of benthos at the bottom of a stream (Thorp, Covich, 2001; Wood et al., 2007). Also, the stability of the substrate is an important feature when it comes to its colonisation by invertebrates (Jowett, 2003). According to Wyżga et al. (2002), the presence of rocky material of high granulity, as well as wood debris favours the accumulation of muddy sediments, fallen leaves and thus creates favourable living conditions for many species. This was also confirmed by research done by Dumnicka et al. (2007). Only at the bottom of evorsion potholes, directly downstream from the hydrological structures, rock material was sorted out and small, which reflected negatively on habitat conditions, making them unfavourable for the development of benthic forms. Similar observations were made, among others, by Kaller and Hartmann (2004).

Temperature significantly affects the development cycles of insects (Brittain, 1982; Kukuła, 1997; Lessard, Hayes, 2003; Haidekker, Hering, 2008; Brown et al., 2010). The life cycle closely associated with temperature fluctuations occurs in, among others, mayflies of the genus Baetis (Sand, Brittain, 2009), which were reported on the tested posts throughout the year and were especially numerous in lower reaches of watercourses, where shading was less intense (facilities B and F). In turn, the greater shading causes less light to reach the bottom of the watercourse and, as a consequence, affects the development of photosynthetic organisms. However, no significant differences in the development of periphyton on the bottom of rivers were observed, with the exception of the Kryściów stream (facility N), but even in this case, the coverage of the substrate by periphyton reached approximately $50 \%$ in some months. The low water temperature, alkalinity and high degree of saturation of water with oxygen were conducive to the development of cryophilic and species living in highly oxygenated water, as well as those sensitive to the level of water pollution. Among them there were representatives of the family Hepteganidae (especially the typically 'mountainous' genera such as Rhithrogena, Ecdyonurus and Epeorus) (Allan, 1998; Bogdanowicz et al., 2007). In the studied sections of watercourses, the concentrations of nutrients had no significant effect on the formation of clusters of mayflies. Both the values of nitrogen and phosphorus compounds fell within the lower limits of acceptable standards (Regulation of the Minister of Environment of 24 July 2006). It should be remembered that the highest concentration of nitrate nitrogen was noted in Łabowa (facility B), whereas that of ammonium nitrogen was recorded in Frycowa (facility F). This was probably due to the fact that these facilities were located in the lower reaches of watercourses, flowing through the countryside. Clarke and Scruton (1997) demonstrated that taxonomic diversity in clusters of benthos is inversely proportional to the concentration of nitrogen. In the present study, probably due to low concentrations of nitrates and ammonium compounds, this theory has not been confirmed - the values of coefficient of taxonomic diversity obtained at different posts were high and close to each other, and the greatest values corresponded to clusters inhabiting the section of the facility $\mathrm{F}$, where the concentration of ammonium nitrogen was highest. For example, mayflies of the genus Habrophlebia, which are relatively sensitive to higher levels of nitrogen, as indicated by Pokorny et al. (2012), were observed in the very Homerka stream, near the town of Frycowa (F).

The taxonomic diversity and abundance of specimens in the betnhos of watercourses are influenced by trophic state index of water, which is shaped, by, among others, the nature 
of the development of the river basin and coastal areas (Kopacz, Twardy, 2006; Galbraith et al., 2008). According Törnblom et al. (2011), mayflies do not show in this regard any clear preferences - at most, the willingly inhabit streams whose basins are agricultural in character (extensive agriculture). Mayflies have a greater environmental tolerance than stoneflies and caddisflies, when it comes to the type of coverage of the basin area (Hughes, 2006; Galbraith et al., 2008; Medhurst et al., 2010). It was confirmed in this study. Representatives of most species of mayflies showed no clear preference as to the nature of the development of the basin on the given sections of watercourses. Many species of the genus Baetis shows a high tolerance to changes in environmental factors within the channel and basin (Bottova et al., 2012). Thus, in the facilities of the lower reaches of streams, where the adjacent part of the basin was agriculturally developed, numerous representaives of the Baetis, as well as Serratella ignita, were observed. In the studies of flowing waters, it has been shown that an increase in the size of a watercourse is positively correlated with an increase in the number of taxa occurring in this watercourse (Clarke et al., 2008; Sheldon, Warren, 2009). This is related to, among other things, the availability and greater diversity of habitats and the diversity of ecological niches (Mykrä et al., 2011). This thesis is confirmed by the fact that the greatest taxonomic richness of mayflies was found in the Homerka creek. In the Homerka, especially in the estuary section (the facility in Frycowa), the roots of trees and shrubs growing on the banks, immersed in water, as well as submerged tufts of grass, and even waste deposited in some places, encouraged a greater diversity of habitats for mayfly larvae. Reported changes in the number of taxa represented in the clusters of mayflies and in the number of particular species were mainly related to their life cycle (Bogdanovich et al., 2007; Alibozek, Ganger, 2008; Błaszak, 2012). Mayflies of the families Baetidae and Heptageniidae were found throughout the year. Some species of the family Ephemerellidae (Ephemerella notata, E. mucronata) were not noticed in summer, while Serratella ignita occurred primarily during the summer months. Representatives of the family Leptopheblidae appeared most frequently in summer and autumn. This is consistent with observations made by Klonowski-Olejnik and Skalski (2014), who proved that for most of the year it is mainly the seasonal occurrence that determines the taxonomic structure of mayfly groupings in the Carpathian basins studies by them. The results obtained are consistent with the data presented in the literature connected with life cycles of mayflies and the scope of their occurrence in Poland (Brittain, 1982; Jażdżewska, 2001; Bogdanovich et al., 2007; Błaszak, 2012).

\section{The presence of hydrological structures}

In lotic environments, one of the factors determining the structure of groupings is the water flow, both its volume and speed. The speed of flow and bottom erosion influence the structure of the bottom substrate, deposition of organic matter and thus the microhabitats and food base of many benthic invertebrates (Small et al., 2008). The structure of the flow is therefore reflected in the structure of microhabitats and groupings inhabiting them (Thorp, Covich, 2001; Parasiewicz, 2003). This affects the distribution of lotic species and those opting for an environment of calmer waters, as well as species preferring certain types of the substrate (Davy-Bowker et al., 2006). In the case of the distribution of mayflies of the Epeorus 
sp, it was demonstrated by Hoover and Ackerman (2011) that flow conditions are more important than food availability and the presence of predators. Organisms react differently to changes in the volume of the flow (Poof, Zimmerman, 2010). It is a more pronounced reaction than in the case of a change in the flow velocity alone. The examined sections of streams, located in the region of small lateral hydrological structures, showed no abrupt changes in species composition and taxonomic richness either between watercourses or types of posts. This was related, among other things, with the fact that the hydrological structures occurring on those streams did not cause changes in the volume of the flow, but only led to a change in its speed on short sections downstream from erosion potholes. Therefore, changes in the groupings differ from changes in the volume of the flow caused by hydrological structures - even structures of small sizes, which, however, have a damming effect on water (Almeida et al., 2009; Gallo et al., 2010; Patterson, Smokorowski, 2011). The fact that mayflies settle in different types of habitats also results from preferences of particular taxa as to the speed of the flow and susceptibility to drift (Armitage, Cannan, 2000; Oldmeadow et al., 2010). It does not always happen, however, that an increase in the values of shear stress is associated with an increased drift (e.g. in the case of certain species of the genus Baetis; Wilcox et al., 2008). In the studied streams, there were representatives of typically rheophilic taxa, which prefer fast flow and show tolerance to high values of shear stress. These were, among others, mayflies of the Rhithrogena sp. and Baetis sp. Mayflies of the Ephemera sp. and Paraleptophlebia sp., as well as Centroptilum luteolum, which were observed on the studied posts, prefer, in turn, slow water flow, e.g. coastal bays with high CPOM concentration (Möbes-Hansen, Waringer, 1998). It was also proven that there were representatives of taxa indifferent to the speed of the flow (e.g. Ephemerella ignita or Ecdyonurus sp.). Despite the fact that on the examined sections of streams, there are hydrological structures reducing the speed of the flow, and there was no significant taxonomic depletion or abrupt changes in the mayfly groupings on the posts located upstream and downstream from the hydrological structures. The faunistic similarity between post types $(1,2,3)$ was big, and the differences in taxonomic richness and abundance of organisms were small, which allows researchers to rule out a significant impact of lateral hygrological structures on groupings of mayflies on the studied sections of streams. Great taxonomic diversity and richness downstream from the structures are also connected with a lack of other structures (e.g. lining up whole channels or their fragments with stone or concrete). The shape of mayfly clusters on the examined streams and their particular sections was not affected as much by small lateral hydrological structures as by seasonal occurrence of taxa, similar type and structure of the bottom substrate, the nature of basin development and the location of a given post on a particular section of the watercourse. Mayfly groupings have been significantly depleted after regulatory works, which is proven by the comparison with research results of the previous years. The issue of the formation of macrobenthic groupings in the region of small lateral hydrological structures requires further research on a larger scale, primarily in other river basins of the Beskids.

\section{Acknowledgements}

I would like to express my deep gratitude for their help to Izabela Czerniawska-Kusza PhD Hab. and Małgorzata Kłonowska-Olejnik PhD. I would also like to thank Ms Katarzyna Niechwiej. 


\section{References}

Alibozek, J. \& Ganger M. (2008). Temporal changes in stream insect abundance inNorthwestern Massachusetts. J. Freshw. Ecol., 23(4), 673-676. DOI: 10.1080/02705060.2008.9664255.

Allan, J.D. (1998). Ekologia wód płynących. Warszawa: Wydawnictwo Naukowe PWN.

Almeida, E.F., Oliveira, L.B., Mugnai, R., Nessimian, J.L. \& Baptista D.F. (2009). Effects of small dams on the benthic community of streams in an atlantic forest area of southeastern Brazil. International Review of Hydrobiology, 94(2), 179-193. DOI: 10.1002/iroh.200811113.

Armitage, P.D. \& Cannan C.E. (2000). Annual changes in summer patterns of mesohabitat distribution and associated macroinvertebrate assemblages. Hydrol. Process., 14, 3161-3179. DOI: 10.1002/1099-1085(200011/12)14:16/17<3161::AIDHYP140>3.0.CO;2-8.

Bajkiewicz-Grabowska, E., Magnuszewski, A. \& Mikulski Z. (1993). Hydrometria. Warszawa: Wydawnictwo Naukowe PWN.

Błachuta, J., Wiśniewolski, W., Zgrabczyński, J. \& Domagała J. (2011). Ocena potrzeb i priorytetów udrażniania ciągłości morfologicznej rzek na obszarach dorzeczy w kontekście osiaggnięcia dobrego stanu i potencjału ekologicznego JCWP. Poznań: RZWG.

Błaszak, Cz. (Ed.) (2012). Zoologia. Tom II. Warszawa: Wydawnictwo Naukowe PWN.

Bogdanowicz, W., Chudzicka, E., Pilipiuk, I. \& Skibińska E. (2007). Fauna Polski. Charakterystyka i wykaz gatunków. Tom II. Warszawa: Muzeum i Instytut Zoologii PAN.

Bottova, K., Derka, T. \& Svitok M. (2012). Life history and secondary production of mayflies (Ephemeroptera) indicate disturbance in two small Carpathian streams. International Review of Hydrobiology, 97(2), $100-116$. DOI: 10.1002 /iroh.201111364.

Brittain, J.E. (1982). Biology of mayflies. Annu. Rev. Entomol., 27, 119-147. DOI: 10.1146/annurev.en.27.010182.001003.

Brittain, J.E. \& Eikeland T.J. (1988). Interbrate drift - a review. Hydrobiologia, 166, 77-93. DOI: 10.1007/BF00017485.

Brown, P.D., Wooster, D., Johnson, S.L. \& Debano S.J. (2010). Effects of water withdrawals on macroinvertebrate emergence: unexpected results for three holometabolous species. River Research and Applications, 28, 347-358. DOI: $10.1002 /$ rra.1460.

Clarke, A., Mac Nally, L., Bond, N. \& Lake P.S. (2008). Macroinvertebrate diversity in headwater streams: a review. Freshw. Biol., 53, 1707-1721.

Clarke, K.D. \& Scruton D.A. (1997). The benthic community of stream riffles in Newfoundland, Canada and its relationship to selected physical and chemical parameters. J. Freshw. Ecol., 12(1), 113-121. DOI: 10.1080/02705060.1997.9663514.

Davy-Bowker, J., Sweeting, W., Wright, N., Clarke, R.T. \& Arnott S. (2006). The distribution of benthic and hyporheic macroinvertebrates from the heads and tails of riffles. Hydrobiologia, 563, 109-123. DOI: 10.1007/ s10750-005-1482-9.

Dukowska, M. \& Grzybkowska M. (2007). Reakcja bentofauny na piętrzenie. Nauka Przyroda Technologie, 1(2),16.

Dumnicka, E., Gallas, J. \& Koperski P. (2007). Benthic invertebrates in Karst Springs: does substratum or location define communities? International Review of Hydrobiology, 92(4-5), 452-464. DOI: 10.1002/iroh.200610991.

Galbraith, H.S., Vaughn, C.C. \& Meier C.K. (2008). Environmental variables interact across spatial scales to structure trichopteran assemblages in Ouachita Mountain rivers. Hydrobiologia, 596, 401-411. DOI: 10.1007/ s10750-007-9124-z.

Gallo, L., De Filippis, A., Mezzotero, A., Voelz, N.J. \& Lucadamo L. (2010). Assessment of the effect of hydrological variations on macrobenthic communities in pools and riffles of a Mediterranean stream. Environ. Monit. Assess., 166, 125-137. DOI: 10.1007/s10661-009-0989-3.

Haidekker, A. \& Hering D. (2008). Relationship between benthic insects (Ephemeroptera, Plecoptera, Coleoptera, Trichoptera) and temperature in small and medium-sized streams in Germany: A multivariate study. Aquat. Ecol., 42, 463-481. DOI: 10.1007/s10452-007-9097-z.

Hawkins, Ch.P. \& Sedell J.R. (1981). Longitudinal and seasonal changes in functional organization of macroinvertebrate communities in four Oregon streams. Ecology, 62(2), 387-397. DOI: 10.2307/1936713.

Hoover, T.M. \& Ackerman J.D. (2011). Microdistribution of a torrential stream invertebrate: Are bottom-up, topdown, or hydrodynamic controls most important? Limnology and Oceanography: Fluids and Environments, 1, 147-162. DOI: 10.1215/21573698-1498042.

Hughes, S.J. (2006). Temporal and spatial distribution patterns of larval trichoptera in Madeiran streams. Hydrobiologia, 553, 27-41. DOI: 10.1007/s10750-005-0627-1. 
Jażdżewska, T. (2001). Distribution in Poland of species of the Baetis group. In E. Dominguez (Ed.), Trends in research in Ephemeroptera and Plecoptera (pp. 259-270). Kluwer Academic/Plenum Publishers.

Jowett, I.G. (2003). Hydraulic constraints on habitat suitability for benthic invertebrates in gravel-bed rivers. River Research and Applications, 19, 495-507. DOI: 10.1002/rra.734.

Kajak, Z. (1992). Ekologiczne skutki zabudowy hydrotechnicznej i wykorzystania wód śródlądowych. In W. Majewski (Ed.), XII Ogólnopolska Szkoła Hydrauliki. Współczesne Problemy Hydrauliki Wód Śródlądowych (pp.17-36). Gdańsk: Instytut Budownictwa Wodnego PAN w Gdańsku.

Kaller, M.D. \& Hartmann K.J. (2004). Evidence of a threshold level of fine sediment accumulation for altering benthic macroinvertebrate communities. Hydrobiologia, 518, 95-104. DOI: 10.1023/B:HYDR.0000025059.82197.35.

Kłonowska-Olejnik, M., Stoch, T. \& Skalski T. (2012). Zgrupowania jętek (Ephemeroptera) w górnej części zlewni Koniny w Gorczańskim Parku Narodowym (Karpaty Zachodnie). Ochrona Beskidów Zachodnich, 4, 57-68.

Kłonowska-Olejnik, M. \& Skalski T. (2014). The effect of enviromental factors of the mayfly communites in headwater streams in the Pieniny Mountains (West Carpathians). Biologia, 69(4), 498-507. DOI: 10.2478/s11756014-0334-3.

Kopacz, M. \& Twardy S. (2006). Zmiany użytkowania ziemi w zlewni górnego Dunajca w aspekcie wybranych parametrów jakościowych wód powierzchniowych. Woda-Środowisko-Obszary Wiejskie, 6(2), 191-202.

Kukuła, K. (1997). The life cycles of three species of Ephemeroptera in two streams in Poland. Hydrobiologia, 353, 193-198. DOI: 10.1023/A:1003051104401.

Kukuła, K. \& Bylak A. (2011). Wpływ czynników antropogenicznych na faunę karpackich dopływów Wisły. Roczniki Bieszczadzkie, 19, 207-222.

Lessard, J.L. \& Hayes D.B. (2003). Effects of elevated water temperature on fish and macroinvertebrate communities below small dams. River Research and Applications, 19, 721-732. DOI: 10.1002/rra.713.

Mazurkiewicz-Boroń, G. \& Starmach J. (2009). Konsekwencje przyrodnicze przegradzania rzek. Chrońmy Przyrodę Ojczysta, 65(2), 83-92.

Medhurst, R.B., Wipfli, M.S., Binckley, Ch., Polivka, K., Hessburg, P.F. \& Salter R.B. (2010). Headwater streams and forest management: Does ecoregional context influence logging effects on benthic communities? Hydrobiologia, 641, 71-83. DOI: 10.1007/s10750-009-0058-5.

Möbes-Hansen, B. \& Waringer J.A. (1998). The influence of hydraulic stress on microdistribution patterns of zoobenthos in a Sandstone Brook (Weidlingbach, Lower Austria). International Review of Hydrobiology, 83(5-6), 381-396. DOI: 10.1002/iroh.19980830506.

Mykrä, H., Heino,J., Oksanen, J. \& Muotka T. (2011). The stability-diversity relationship in stream macroinvertebrates: influences of sampling effects and habitat complexity. Freshw. Biol., 56, 1122-1132. DOI: 10.1111/j.13652427.2010.02555.x

Niechwiej, A. (2013). Wpływ poprzecznej zabudowy hydrotechnicznej na zgrupowania chruścików (Trichoptera) w dopływach Kamienicy Nawojowskiej (Beskid Sądecki). Chrońmy Przyrodę Ojczystą, 69(6), 483-493.

Niechwiej, A. (2015). Regulation of mountain streams versus ecological balance as illustrated by the example of the upper Vistula basin (part I). Scientific Review Engineering and Environmental Sciences, 24(3), 301-310.

Oldmeadow, D.F., Lancaster, J. \& Rice S.P. (2010). Drift and settlement of stream insects in a complex hydraulic environment. Freshw. Biol., 55, 1020-1035. DOI: 10.1111/j.1365-2427.2009.02338.x.

Olsen, D.A. \& Watzin M.C. (2009). Do agricultural pollutants affect competition between filter-feeding caddis fly larvae? Results of laboratory microcosm experiments. Freshw. Biol., 54, 406-416. DOI: 10.1111/j.13652427.2008.02113.x.

Parasiewicz, P. (2003). Upscaling: Integrating habitat model into river management. Canadian Water Resources Journal, 28(2), 283-299. DOI: 10.4296/cwrj2802283.

Patterson, R.J. \& Smokorowski K.E. (2011). Assessing the benefit of flow constraints on the drifting invertebrate community of a regulated river. River Research and Applications, 27, 99-112. DOI: 10.1002/rra.1342.

Pedersen, M.L. \& Friberg N. (2007). Two lowland stream riffles - linkages between physical habitats and macroinvertebrates across multiple spatial scales. Aquat. Ecol., 41, 475-490. DOI: 10.1007/s10452-004-1584-x.

Plotnikoff, R.W.C. \& Wiseman C. (2001). Benthic macroinvertebrate biological monitoring protocols for rivers and streams. Washington Department of Ecology, Publication No. 01-03-028, Olympia, WA.

Poff, N.L. \& Zimmerman J.K.H. (2010). Ecological responses to altered flow regimes: a literature review to inform the science and management of environmental flows. Freshw. Biol., 55, 194-205. DOI: 10.1111/j.13652427.2009.02272.x.

Pokorny, N., Fesl, Ch., Schagerl, M. \& Waringer J. (2012). Factors structuring macroinvertebrate communities in a 
haedwater streams and its springs in the upper Austrian limestone Alps. River Research and Applications, 28(5), 637-646. DOI: 10.1002/rra.1474.

Radecki-Pawlik, A. (2012). Budowle hydrotechniczne w korytach rzek górskich. In K. Krzemień (Ed.), Struktura koryt rzek i potoków (studium metodyczne) (pp. 55-77). Kraków: Instytut Geografii i Gospodarki Przestrzennej UJ.

Rozporządzenie Ministra Środowiska z dnia 24 lipca 2006 r. w sprawie warunków, jakie należy spełnić przy wprowadzaniu ścieków do wód lub do ziemi, oraz w sprawie substancji szczególnie szkodliwych dla środowiska wodnego, Dz.U. 2006 nr 137 poz. 984

Sand, K. \& Brittain J.E. (2009). Life cycle shifts in Baetis rhodani (Ephemeroptera) in the Norwegian mountains. Aquat. Insects, 31(Suppl. 1), 283-291. DOI: 10.1080/01650420902732362.

Sandin, L. \& Johnson R.K. (2004). Local, landscape and regional factors structuring benthic macroinvertebrate assemblages in Swedish streams. Landsc. Ecol., 19, 501-514. DOI: 10.1023/B:LAND.0000036116.44231.1c.

Sheldon, A.L. \& Warren M.L., Jr. (2009). Filters and templates: stonefly (Plecoptera) richness in Ouachita Mountains streams, U.S.A. Freshw. Biol., 54, 943-956. DOI: 10.1111/j.1365-2427.2008.02144.x.

Small, M.J., Doyle, M.W., Fuller, R.L. \& Manners R.B. (2008). Hydrologic versus geomorphic limitation on CPOM storage in stream ecosystems. Freshw. Biol., 53, 1618-1631. DOI: 10.1111/j.1365-2427.2008.01999.x.

Thorp, J.H. \& Covich A.P. (Eds.) (2001). Ecology and classification of North American freshwater invertebrates. Academic Press.

Törnblom, J., Angelstam, P., Degerman, E., Henrikson, L., Edman, T. \& Temnerud J. (2011). Catchment land cover as a proxy for macroinvertebrate assemblage structure in Carpathian Mountain streams. Hydrobiologia, 673, 153-168. DOI: 10.1007/s10750-011-0769-2.

Wilcox, A.C., Peckarsky, B.L.,Taylor, B.W. \& Encalada A.C. (2008). Hydraulic and geomorphic effects on mayfly drift in high-gradient streams at moderate discharges. Ecohydrology, 1, 176-186. DOI: 10.1002/eco.16.

Wood, P.J., Hannah, D.M. \& Sadler J.P. (Eds.) (2007). Hydroecology and ecohydrology: Past, present and future. Willey Online Library, http://onlinelibrary.wiley.com (10.10.2012).

Wyżga, B., Kaczka, R.J. \& Zawiejska J. (2002). Gruby rumosz drzewny w ciekach górskich - formy występowania, warunki depozycji i znaczenie środowiskowe. Folia Geographica, Series Geographica-Physica, 33-34, 117-138.

Wyżga, B., Bojarski, A., Jeleński, J. \& Zalewski J. (2008). Zagrożenia dla zrównoważonego stanu środowiska cieków karpackich i proponowane działania zaradcze. In B. Wyżga (Ed.), Stan środowiska rzek południowej Polski $i$ możliwości jego poprawy - wybrane aspekty (pp. 121-133). Kraków: Instytut Ochrony Przyrody PAN.

Wyżga, B., Oglęcki, P., Radecki-Pawlik, A. \& Zawiejska J. (2011). Diversity of macroinvertebrate communities as a reflection of habitat heterogeneity in a mountain river subjected to variable human impacts. In A. Simmon, S.J. Bennet \& J.M. Castro (Eds.), Stream restoration in dynamic fluvial systems: Scientific approaches, analyses, and tools (pp. 189-207). Washington: American Geophysical Union.

Zaćwilichowska, K. (1968). Bootom fauna in the basin of the river Kamienica Nawojowska. Acta Hydrobiologica, 10, 319-341.

Zasępa, P., Kłonowska-Olejnik, M. \& Radecki-Pawlik A. (2006). Wpływ wybranych zmian abiotycznych w rejonie łachy żwirowej potoku górskiego na mikrosiedliska makrobezkęgowców dennych. Infrastruktura i Ekologia Terenów Wiejskich, 4(2), 221-232. 